\title{
Colonel John Graham of Fintry and the Fourth Cape Eastern Frontier War, 1811-1812
}

\author{
Johan de Villiers ${ }^{\bullet}$
}

Not much is nowadays remembered of Colonel John Graham in South Africa. His name is perpetuated in the city of Grahamstown, Eastern Cape, and the name of a primary school at Plumstead, Cape Peninsula. Buried in the old Wynberg cemetery, Somerset Road, his grave is today unidentified and lost forever.

Johan Graham was the second son of Robert Graham of the Fintry Estate in Forfarshire, Scotland. He was born at Dundee on 24 April 1778 and inter alia taught by the learned Professor John Playfair and Josiah Walker, tutor at Athol House. At the age of 16 years Graham was gazetted Ensign in the $85^{\text {th }}$ Regiment of Foot, but he never joined this regiment, because in the same year (1794), having assisted his cousin, Thomas Graham of Balgowan (afterwards Lord Lynedoch), to recruit candidates for the $90^{\text {th }}$ Regiment of Foot (Perthshire Volunteers), he was promoted to a Lieutenancy in that regiment. ${ }^{1}$

In July 1795, commanding a company of this regiment, he served on the Isle de Dun, off the coast of France. Ill health compelled him in December that year to return to England. After recovering, in March 1797, the Duke of York, Commander-in-Chief, granted him permission to join the Austrian Army temporarily. His cousin, by that time Colonel Thomas Graham, also served in the Austrian Army. In 1799 John Graham took part in military actions against the French republican forces in Northern Italy, viz. at Adiye (26 March),Verona (30 March) and Villa Franca (5 April). ${ }^{2}$

In June 1799 he presumably returned to England on board a vessel under command of Admiral Samuel Hood, whose fleet occupied the French harbour of Toulon and also captured many French ships in the Mediterranean. ${ }^{3}$ Back in England, Graham became aide de camp to Lord Chatham whom he accompanied to Holland in September. He served in that country until the withdrawal of all British forces in February 1800. Subsequently he recruited volunteers for the $93^{\text {rd }}$ Regiment of Foot in Scotland. He was appointed Major of this regiment and from October 1800 served with his troops on the Channel Island of Guernsey. In October 1802 he returned with his regiment to Scotland. After receiving the Reserve in Ireland, he took command of a battalion of Light Infantry Militia until being appointed Assistant Quartermaster General for the period February 1804 to July $1805 .^{4}$

\footnotetext{
- Professor of History, University of Zululand. Scottish Record Office (hereafter S.R.O.), G.D. 151/3/1 Graham of Fintry Letters ${ }_{2}$ Undated notes, pp. 4-5. Ibid.

South African Biographical Dictionary. I, p. 329; D.M.G. Sutherland, France 1789-1815, (London, 1985), p.189. 
At the resumption of the Napoleonic wars in Europe, the strategic importance of the Batavian colony at the Cape of Good Hope was apparent to the British Government. ${ }^{5}$ In July 1805 Graham embarked with his regiment on "secret foreign service" under supreme command of Major-General Sir David Baird. It was only after leaving the Brazilian harbour of Saint Salvador that sealed Instructions were opened, indicating the British Government's immediate objective to take over the hostile Batavian Government of the Cape Colony. 6

During the landing of British troops at Losperd's Bay on 6 January and the subsequent battle on the Blaauwberg flats on 8 January 1806, Major John Graham commanded the combined British Light Infantry with distinction. The loose sand and heat hampered their progress, but Cape Town and its fortifications were occupied without any further resistance of the local citizens. After the final capitulation of the Colony by General Jan Willem Janssens, Baird ordered Graham to immediately "raise and discipline" a regiment of native Khoi and Coloured people, which soon became known as the Cape Regiment. Graham officially became Lieutenant-Colonel and local commanding officer of this regiment on 26 January $1806{ }^{7}$ Graham's regiment fulfilled a key role in the defence of the Cape Colony, especially due to the urgent withdrawal of several other British regiments from the Colony and the special characteristics of the indigenous soldiers who were enlisted and trained by mainly British officers at the regimental headquarters in Wynberg, Cape Peninsula. ${ }^{8}$

Graham soon proved to be an energetic and versatile regimental commander. According to his own testimony, in addition to his mother tongue English-Gaelic, he was "tolerable proficient" in Dutch, Italian, German and French. He communicated well with the soldiers and local citizens at the Cape, being a practical organiser and inspiring leader. ${ }^{9}$ It seems that Graham's main challenge was twofold, viz.

- to recruit and enlarge the Cape Regiment with the best available local Khoi and Coloured talent, and

- to overcome any assumed prejudices of local citizens against this new regiment, by maintaining a clear and pro-active conciliatory approach.

By 1911 serious problems in the eastern frontier districts of the Colony required the complete involvement of John Graham and his regiment.

On both sides of the official Fish River boundary of the Colony successive phases of conflict erupted between the different cattle herding communities, ignoring the frontier arrangements of Governor Joachim van Plettenberg in 1778. Nine eastern frontier wars followed which only terminated a century later and which may be holistically interpreted as one long period of conflict of fluctuating intensity. ${ }^{10}$

$5 \quad$ Cape Archives (hereafter C.A.), B.R. 73 Bijlagen: Extract Secreete Notulen, 11 June 1805, 547-551.

S.R.O., G.D. 151/5 Graham of Fintry Letters : John Graham to "a particular friend in Dublin", 16 March 1806 , no. 34 .

S.R.O., G.D. 151/3/2 Graham of Fintry Letters : Statement of Service of Lieutenant-Colonal John Graham, 29 Dec. 1809 , p. 556.

The African Court Calendar : List of the Army at the Cape of Good Hope, 1806-1810, no pages.

9 S.R.O., G.D. 151/3/2 Graham of Fintry Letters : Statement of service of John Graham, 29 December 1809 , p. 556.

10 Vide e.g. A.J. Smithers, The Kaffir Wars (London, 1973). 
The eastern frontier zone of the Cape Colony may be defined as a region or territory of inter-penetration between various distinct societies. During most of the nineteenth century different societies competed and interacted on the gradually closing frontier, each attempting to achieve hegemony. ${ }^{11}$

In cases of large scale cross-border raids and thefts, isolated white and Khoi farmers claimed protection from the distant Colonial authorities, whose main concern seemed to cut back financial expenses. The Colonial farmers were favoured by their mobility (horses) and fire-arms, but lacked cohesion and numerical strength. By 1811 the estimated official population figures of the two eastern frontier districts were as follows: ${ }^{12}$

\begin{tabular}{|l|l|l|l|}
\hline POPULATION & $\begin{array}{l}\text { WHITE MEN \& } \\
\text { WOMEN }\end{array}$ & $\begin{array}{l}\text { KHOI MEN \& } \\
\text { WOMEN }\end{array}$ & $\begin{array}{l}\text { SLAVE MEN \& } \\
\text { WOMEN }\end{array}$ \\
\hline Uitenhage & 1111 & 1224 & 580 \\
\hline Graaff-Reinet & 2619 & 3544 & 1499 \\
\hline Total & 3730 & 4768 & 2079 \\
\hline
\end{tabular}

By 1811 at least 20000 Xhosa intruders had already crossed the Fish River boundary into the grassy Zuurveld and beyond. Their numerical strength must be added to their intimate knowledge of and adaptability to the physical environment of indigenous vegetation, steep ravines and treacherous river crossings. Xhosa fighters used to conceal themselves in dense thickets by wrapping their skin cloaks around their bodies to protect themselves against thorns. ${ }^{13}$

The vanguard of white stock-farmers moving eastwards, and Xhosa cattle-herders migrating westwards, caused rivalry on the eastern frontier, especially in the contested Zuurveld, between the Sundays and Fish Rivers. Each group resisted the advance of the other, particularly when population increased in a limited area. Within Xhosa ranks further stress was generated by a dynastic feud between Ngqika, paramount Chief of the western Xhosa, and Ndlambe, his uncle and former regent.

While John Graham accumulated and trained an efficient Cape Regiment at its headquarters in Wynberg, Major Jacob Glen Cuyler, his immediate deputy officer stationed at Fort Frederick, Algoa Bay, recommended in 1808 that the Colonial authorities set an ultimatum to all Xhosa intruders west of the Fish River to withdraw from their abodes before a given date. Graham supported this suggestion, but the Cape Governor, the Earl of Caledon, maintained that only the official policy of "preserving what we possess" should be applied on the eastern frontier, avoiding any form of offensive action. ${ }^{14}$

Serious concerns arose when Chief Ndlambe's followers settled close to the Sundays River. By the end of 1809 it seemed that a combined Xhosa invasion of the Zuurveld was immanent. Echoing official policy, Graham warned Cuyler to refrain from any aggressive

13

H.Lamar and L.Thompson (eds), The Frontier in History, (New Haven, 1981), pp. 7-9.

Public Record Office (hereafter P.R.O.), W.O. 1/635 Commander-in-Chief: Graham - Hope, 18 Nov. 1806, pp. 51-58.

J. Campbell, Travels in South Africa (London, 1822), pp. 118-119, 374.

C.A., G.H. 34/4 Letter Book : Caledon - Collins, 14 Nov. 1808, p. 80. 
From the above statistics it is clear that Graham could only rely on the Light Dragoons for swift operational tasks; the last three regiments being infantry that could merely be used to defend strategic posts. Numerically Graham's Cape Regiment was by far the biggest in number ( 30 officers and $522 \mathrm{men}$ ) and also best adapted to perform fatigue duties in the unique frontier environment.

Graham personally attended to the transportation of the military reinforcements, equipment and ammunition on board the UPTON CASTLE to Algoa Bay. On arriving at the Drostdy of Uitenhage, 27 October 1811, he spent some weeks personally observing the extent of Xhosa occupation of the frontier districts. ${ }^{27}$

On 21 November he ordered the troops to move their military posts in an eastward direction, closer to the Fish River boundary. This would enhance the protection of more farms, extend the military communication lines and provide strategic support to any contemplated Commando operation. ${ }^{28}$ In the district of Graaff-Reinet, Graham concentrated the bulk of Lyster's troops at Bruintjes Hoogte. The left flank of Lyster's posts stretched from Bruintjes Hoogte to the Baviaans River, a northern tributary of the Great Fish River. The right flank of Lyster's posts stretched from Bruintjes Hoogte to the Riet (or Vogel) River, where the cavalry $\left(21^{\text {st }}\right.$ Light Dragoons) were stationed. ${ }^{29}$

Graham's grand strategy to clear the eastern frontier of Xhosa invaders was carefully planned. He warned Major Lyster that in case of forceful operations against the Xhosa, some may succeed to move unobserved in a westward direction, rather than crossing the Fish River. The reserve troops at the various outstretched posts must be on the qui vive for such Xhosa that may attack them from the back, especially during the night. Any roaming Xhosa found during day time, must be disarmed and forced over the eastern boundary. ${ }^{30}$ Graham instructed Lyster to:

- keep the exact number of reserve troops at the various posts secret,

- use only a part of the reserve troops at a post for patrol work,

- avoid entering dense forests where the enemy could wait in ambush,

- notify Graham immediately when any Xhosa chief is found and held at a post,

- strategically withdraw the reserve troops from the posts in case of being completely outnumbered and over-powered by a major enemy onslaught, and

- defend at all costs the drostdy and administrative centre of Graaff-Reinet.

Graham evidently took into account the particular needs and circumstances at the different posts, by allowing discretionary powers to commanding officers of the reserve troops. ${ }^{31}$

\footnotetext{
27 C.A., G.H. 23/4 Despatch Book : Cradock - Liverpool, 18 October 1811, no.3; S.R.O., Ex G.D. 151/2/1 Graham of Fintry Muniments : Graham - Reynell, 29 October 1811, pp. 1-2.

28 C.A., C.O. 33 Letters Received : Graham - Reynell, 21 November 1811, no.29. 
In addition to the defensive function of the advanced frontier posts, Graham's strategy was meticulously presented in his General Instructions of November 1811, whereby a wellplanned and bold trifid offensive had to be launched against the Xhosa intruders of the frontier districts. For this purpose he called upon all available armed citizens of Graaff-Reinet and Uitenhage, under their respective Landdrosts, as well as a proportion of regular troops, including the Cape Regiment. The three divisions of the contemplated force comprised of

- a right division, close to the coast, commanded by Cuyler, Landdrost of Uitenhage,

- a central division, commanded by Captain George Sackville Fraser of the Cape Regiment, and

- a left division, from the district of Graaff-Reinet, commanded by Landdrost Anders Stockenström. ${ }^{32}$

Graham allowed ample time for the farmers to finish the wheat harvest, before they were to join the Commando under their civil leaders, e.g. Field-Commandant Gabriël Stoltz, and Fieldcornets Willem Grobler and Willem Nel. ${ }^{33}$

In the mean time Graham had to resolve a storm in a teacup, when Landdrost Stockenström complained to him that Lyster had ignored the civil authority by instructing armed civilians of the reserve force to serve under officers of the Army. Graham responded that Lyster was a most experienced officer and appointed in command of all the reserve forces. It was impossible for Stockenström simultaneously to command the left wing of the Colonial task force, as well as the reserve forces in the district. ${ }^{34}$

At the Drostdy of Uitenhage some Khoi scouts reported to Graham on 22 November that they had visited the main settlement ("kraal") of Habana in the Rietberg. They found this petty Chief, a cousin of Ndlambe, in a desperate condition. He was old and sickly. He seemed unprepared for war and afraid of the British. Graham expected that Habana would remove his followers and cattle peacefully over the eastern boundaries. ${ }^{35}$ At the beginning of December 1811 he sent Landdrost Stockenström as emissary to the headquarters of Chief Ngqika outside the Colony, in the Tyumie Valley, east of Kat River. This paramount Chief agreed to Stockenström that he would allow his traditional rival Ndlambe and followers to cross and settle east of the Fish River. Graham welcomed the status quo with Ngqika, but did not trust him. ${ }^{36}$

An incident took place near the town of Uitenhage, on 2 December 1811, which triggered the outbreak of the Fourth Frontier War. Graham was informed that the Xhosa fighters attacked a small mounted military patrol, killing one member (Swartz) and taking eight horses. An immediate follow-up operation proved fruitless and Graham concluded:

32 C.T. Atkinson (ed.), Supplementary Report on the Manuscripts of Robert Graham of Fintry (Historical Manuscripts Commission publication no. 81, London, 1942), p.88

P.L. Zietman, Die Verdediging van en Verdedigingsbeleid op die Oosgrens (M.A. dissertation, UNISA, 1941), p. 69

S.R.O., Ex G.D. 151/2/1 Graham of Fintry Muniments: Graham - Stockenström, 7 December 1811, pp. 2830.

C.A., C.O. 33 Letters Received: Particulars of a conversation between Habana and three Hottentots, undated, enclosure in no. 29.

Ibid., Graham - Reynell, 12 December 1811, no.32. 
'I gave them orders, if they could get the murderers, to shoot them immediately, for sorry I am to say, that reasoning with these savages is of no avail...,37

The three organised military divisions to clear the frontier districts of Xhosa intruders, commenced with their task on 20 December, utilising the visibility of full moon in nighttime. On 26 December the right wing of Ndlambe's forces that were well hidden in the bush, confronted the division of Cuyler. The Chief stepped forward and loudly challenged Cuyler, stating that he had conquered the Zuurveld in a previous war and that he would not voluntarily yield it. He then raised his assegai as a signal to his followers to attack. The warriors, however, did not approach the troops close enough to experience the effectiveness of the Colonial firearms. ${ }^{38}$ It was evident that Ndlambe had rallied all the Zuurveld Xhosa in a war of resistance against Graham's clearing up operation. Graham decided to concentrate all his available forces (three divisions) at Zokamma (also known a Coerney), about 16 kilometres northeast of the mouth of the Sundays River, in order to prepare for a combined military attack on Ndlambe's stronghold in the Addo Bush.

Graham instructed Landdrost Stockenström to move the left division over the passes of the Zuurberg and Rietberg to join Fraser's central division in the vicinity of Korhaan Drift on the Sundays River. ${ }^{39}$ On the evening of 29 December Graham received the alarming news that Stockenström, who first wished to consult him personally, had fallen with eight of his mounted party, including the Fieldcornets Potgieter and Greyling, and a Coloured interpreter, in a surprise attack that morning at Doorn Nek in the Zuurberg. This tragic incident was executed by the imiDange warriors of petty Chief Xasa, who refused to negotiate the removal of his people across the Fish River boundary. ${ }^{40}$

Graham insisted that the left division must link up with Fraser's central column for the contemplated combined operations. This took place at Zokamma on New Year's day 1812, where Graham assembled a combined force of about

$\begin{array}{lr}\text { Royal Artillery } & 30 \text { men } \\ 21^{\text {st }} \text { Light Dragoons } & 20 \text { men } \\ \text { Cape Regiment } & 400 \text { men } \\ \text { Armed citizens } & \underline{350 \text { men }} \\ \text { Total } & \underline{800 \text { men }}\end{array}$

$37 \quad$ Ibid.

S.R.O., Ex G.D. 151/2/1 Graham of Fintry Muniments : Cuyler - Graham, 26 December 1811, pp. 38-39. C.A., C.O. 2582 Letters Received : Extract of a private communication of Lieutenant-Colonel Graham, 2 January 1812, enclosure in no. 50.

Sir Andries Stockenström: The Autobiography of ... (Edited by C.W.Hutton, Struik, Cape Town, 1964), pp. $57-61$

C.A., C.O. 2582 Letters Received : Extract of a private communication of Lieutenant-Colonel Graham, 2 January 1812 , enclosure in no.50. 
On 2 January he organised them in six companies, each comprising of 60 armed citizens and 20 Cape Regiment soldiers, to sweep the Addo forest on foot from the north, shooting all male Xhosa and seizing all cattle. This was the first time that Colonial troops were used to systematically scour thickets on foot in this frontier war. It proved to be less successful, because agile Xhosa warriors could easily evade the heavily armed soldiers under cover of the natural vegetation and physical terrain. After five days of fatiguing service, the parties returned reporting that they could only eliminate 12 or 14 Xhosa, including the old Chief Chungwa, who was hiding in the bush, but that Field cornet Nortjé was also killed by an assegai of the enemy. The various Colonial companies confiscated 2500 cattle during the operation. ${ }^{42}$

To expedite the expulsion of all intruding Xhosa from the frontier districts, Graham requested Governor Cradock on 8 January to transfer at least 200 additional regular soldiers of the Cape Garrison to reinforce the frontier troops and to enable him to fully deploy the Cape Regiment for operational duties in the guerrilla warfare against the Xhosa. ${ }^{43}$ To this request the Governor responded swiftly by ordering the embarkation of 200 rank and file and officers of the $60^{\text {th }}$ Regiment of Foot to Algoa Bay. ${ }^{44}$

By the end of January Graham ascertained that Ndlambe and his immediate subjects, with all their cattle, had evacuated the coastal war zone between the Sundays and Fish Rivers. They retreated eastwards across the Colonial boundary on 14 or 15 January, followed also by remnants of the community of the fallen Chungwa. ${ }^{45}$

This enabled Graham to attend to deteriorating conditions in the Bamboesberg, where the wife of a farmer (van der Merwe) and several Khoi cattle herders had been killed by Xhosa marauders, seizing several droves of cattle. Graham ordered that armed citizens and soldiers of the Cape Regiment be henceforth mounted for quick retaliatory expeditions. They were to track stolen cattle to the hiding places of the Xhosa and to kill male inhabitants indiscriminately. ${ }^{46}$

The Xhosa Chief Habana, who seemed unprepared for war in November 1811, subsequently provided sanctuary to numerous hostile Xhosa leaders and fugitives at his stronghold in the Rietberg. Graham decided to launch a simultaneous twofold attack on Habana's sanctuary. On 24 January 1812 some 150 men from Graaff-Reinet were to attack Habana's place from the north, while Fraser with an equal number of soldiers had to assail it from the south. Habana's warriors skillfully avoided any direct confrontation with the troops, withdrawing time and again into the vast overgrown ravines of the Rietberg. Graham, however, responded by sending an additional 200 fresh soldiers of the Cape Regiment to continue the offensive with orders to kill or drive all Xhosa invaders over the eastern boundary. ${ }^{47}$ At daybreak, on 13 February, a twelve day sweeping operation of the northern and southern slopes of the Rietberg started. The troops covered a distance of about 65 kilometres of deep valleys and nearly inaccessible ravines. They applied a scorched earth policy by destroying all Xhosa gardens and crops and seizing some 600 cattle. About 30 male Xhosa were killed in action, but

C.A., G.H. 28/4 Enclosures to Despatches : Graham - Reynell, 8 January 1812, no. 12.

43 C.A., C.O. 2582 Letters Received, Graham - Reynell, 8 January 1812, no. 50.

44 C.A., G.H. 23/4 Despatch Book : Cradock - Liverpool, 23 January 1812, p.28.

45 C.A., C.O. 2582 Letters Received : Graham - Alexander, 30 January 1812, no.5.

$46 \quad$ Ibid

47 C.A., C.O. 2582 Letters Received : Graham - Reynell, 31 January 1812, enclosure 4 in no. 50.
} 
more than 100 Xhosa women and children were also taken captive by the troops and sent over the Colonial boundary via Bruintjes Hoogte. Graham was convinced that this military operation had unequivocally demonstrated to the Xhosa intruders that no hiding place in the frontier districts was inaccessible to the Colonial forces. ${ }^{48}$

By the end of February Graham reported to Governor Cradock that all resistance of Xhosa intruders in the frontier districts had been broken and that "hardly a trace" of them had remained. ${ }^{49}$ For all practical purposes the Fourth Frontier War had ended. On 7 March the Governor announced in a general Communiqué that Graham's troops had successfully swept some 20000 Xhosa intruders out of the Zuurveld in just two short months. A minimum of blood had been shed, but the Xhosa leaders practically experienced the effectiveness, extent and hegemony of Colonial military power. ${ }^{50}$ The Governor reported to the Commander-in-Chief at the Horse Guards that

'Lieutenant-Colonel Graham of the Cape Regiment, in whose hands all the civil and military power was lodged, has conducted the whole course of the proceedings with the greatest ability and good management, and has expressed himself in the most favourable terms of every part of the military force under his command. The success that has attended the measures pursued, has gone beyond expectation and the expulsion of the (Xhosa intruders) from His Majesty's territory into their own country, effected in the manner it has been done, with so little violence, seems to receive universal satisfaction and will give a peace and security to the frontiers of this settlement hitherto unknown...,51

But the termination of the war did not end Graham's commitment to arrange the necessary measures for a lasting peace and stability in the frontier districts. He firstly improved lines of communication by opening strategically important roads in the Zuurveld. Soldiers and civilians were utilised to repair the old route from Korhaan Drift (Sundays River) to Rautenbach's Drift (Bushman's River) and a new road over the Addo Pass. ${ }^{52}$

To seal off the Fish River boundary, Graham established 22 military posts between the Great Winterberg and the sea. The posts formed two lines of defense. The front line stretched from Esterhuyzen's Post (east of Slachter's Nek) to Old Kaffir Drift (near the mouth of the Fish River). The second line of military posts linked Bruintjes Hoogte and Groenfontein. The bulk of patrol work was allocated to the Cape Regiment, whose soldiers were mounted partly on pack oxen due to horse-distemper that prevailed in the frontier regions. The rest of the patrols consisted of farmers called up from different districts for particular periods of service. ${ }^{53}$

In collaboration with Governor Cradock Graham envisaged a relatively dense farming population close to the eastern borders of the Colony, to form a cordon of small semi-military

48

S.R.O., G.D. 151/3/2 Graham of Fintry Letters : Graham - Reynell, 26 February 1812, no. 174; P.R.O., W.O. 1/343 Despatches : Graham - Cradock, 26 February 1812, p. 156.

Ibid.

S.R.O., G.D. 151/7/1 Graham of Fintry Letters : Communiqué, 7 March 1812, p.13.

P.R.O., W.O. 1/343 Despatches : Cradock - Torrens, 8 March 1812, pp.143-158.

S.R.O., G.D. 151/3/2 Graham of Fintry Letters: Graham - Reynell, 26 February 1812, no. 174.

S.R.O., G.D. 151/2/1 Graham of Fintry Muniments : Graham - Reynell, 20 March 1812, pp. 39-40. 
settlements. ${ }^{54}$ Graham selected the abandoned loan farm of Lucas Meyer, "De Rietfontein", as new headquarters of the Cape Regiment. It was strategically situated in the Zuuveld, about 30 kilometres from the Fish River boundary. In June 1812 the first temporary barracks of wattle and daub were constructed on high level ground for the new military centre on the Kowie River. $^{55}$

To honour the exceptional services rendered by Graham and his associates during the Fourth Frontier War, Governor Cradock in August 1812 proclaimed that the new military centre on the banks of the Kowie River must be officially called Graham's Town. It soon also developed into a major administrative and commercial centre. ${ }^{56}$

\section{Conclusion}

What made the Fourth Frontier War and John Graham's role remarkable? Firstly, a relatively small number of heterogeneous colonial forces, comprised of regular soldiers and armed civilians, in total an offensive force of about 1000 men, effectively cleared the frontier districts of about 20000 Xhosa intruders within a short period of about two months. Graham's motivational skills, organisational talents and military experience blended them into concerted action against a common foe, notwithstanding previous years of escalating tension, loss of lives and property and even the large scale evacuation of loan farms in the frontier districts.

Secondly, one should note that the War was traumatic to the Xhosa, because they experienced the full military power of the Colonial forces. At the very moment of their perceived control of the vast extents of the Zuurveld and Rietberg, they were confronted with colonial opponents whose fire-power and mobility they could not match. According to the Xhosa prophet Nxele (alias Makana or Links) the Xhosa easily credited the Colonial forces with the mystical power of the "spirits who lived below the sea". 57

Although Xhosa leaders such as Ndlambe, Chungwa and Habana claimed a right to occupy the frontier districts on account of conquests during previous wars, they failed to maintain their supremacy. Individual property rights did not exist among the Xhosa, but they adhered to communal occupation of the best arable and grazing lands and specific spheres of influence. They were not unaccustomed to a mobile life style based on seasonal changes, but not to the same extent as the Khoi or San in the interior of the sub-continent. ${ }^{58}$

The evasive tactics of the Xhosa in guerilla warfare enabled them to avoid heavy casualties and to equalise the assegai and firearm in hand to hand fighting in the thickets. But the Xhosa were hampered in coherence from the very beginning of the war. Ndlambe fled with his followers and cattle across the Fish River, leaving Chungwa to resist the Colonial forces.

\footnotetext{
54 C.A., C.O. 4831 Letter Book : Alexander - Graham, 2 April 1811, pp. 395-396.

55 S.R.O., G.D. 151/Box 11 Graham of Fintry Letters : Graham - Reynell, 15 May 1812, no. 10/87/7.

56 Cape Town Gazette and African Advertiser: Proclamation, 14 May 1812 and Advertisement, 14 August 1812 , p.1.

57 Janet Hodgson, 'Plugging in to Sources of Power' (Paper presented at the Sixth Congress of the Association for the Study of Religion, U.Z., 27-28 June 1984), p. 2.

58 John Milton, The Edges of War (Juta, Cape Town, 1983), p. 25.
} 
Habana collected many renegades and Xhosa marauders in the Rietberg, but isolated himself from his superiors east of the Fish River boundary.

The real reason for the frontier conflict was clearly identified by Graham and his associates as a clash about similar means of subsistence between the eastward moving extensive cattle farmers of the Colony and the westward moving Xhosa cattle herders in the disputed frontier zone. The pressures of population growth, internal strife and succession problems complicated the closing frontier situation for the Xhosa intruders. ${ }^{59}$

To reinforce his limited number of regular troops, Graham called upon the armed citizens of the frontier districts to defend their families and property in the crisis situation. Graham utilised the traditional Commando system for practical reasons. The farmers were familiar with their own local leaders and the physical environment. They had to victualise themselves and use their own horses for brief periods of military service. It implied a financial saving to the authorities and the promotion of self-interest of civilians. ${ }^{60}$ Nonetheless, Graham arranged commissariat services for the regular troops and armed citizens who were utilised for lengthy periods in the reserve force and at the new frontier posts. This created a market for local entrepreneurs and contractors such as Piet Retief. ${ }^{61}$ Supplies were also sent from Cape Town by ox wagon or ship through the agent Robert Hill. ${ }^{62}$

Another remarkable fact of the Fourth Frontier War is the limited loss of lives, as officially reported. War is always horrible, traumatic and destructive, but Graham succeeded to restrain the anger and ruthlessness of his troops in relation to the grand objectives of his frontier arrangements. The lives of Xhosa women and children were saved during the campaign against Habana, but immediate revenge motivated the forces against the imiDange after the tragic death of Landdrost Stockenström and his party at Doorn Nek. It is very unlikely that Graham or Governor Cradock would have underplayed the real number of Xhosa casualties during the frontier operations. ${ }^{63}$

How permanent was the outcome of the Fourth Frontier War? With the wisdom of hindsight it is possible to conclude that Graham's successful military campaign and frontier arrangements did not last long. After he and Cradock had left the Colony, new administrators lacked the zeal and resources to maintain a strict border control and defensive system. Financial interests surpassed the 'luxury' of military and security needs, regulated from Cape Town and London. $^{64}$

An assessment of John Graham as leader needs some perspective. Leadership is usually determined by an immediate crisis. During the Fourth Frontier War, Graham became the leader of the moment. His relatively brief period as civil and military commissioner in the frontier was preceded by a long record of excellent military service abroad and in the Cape Colony, where he

\footnotetext{
$59 \quad$ Ibid., p.61.

60 Vide Pieter E. Roux, 'Geskiedenis van die Burgerkommando's in die Kaapkolonie' (D.Phil. thesis, U.S., 1946).

J.L.M. Franken, Piet Retief se Lewe in die Kolonie (Nasionale Pers, Cape Town, 1949), p. 71.

C.A., G.H. 34/2 Indian Letter Book: Cradock - Farquhar, 13 July 1813, no numbers.

S.R.O., G.D. 151/7/1 Graham of Fintry Letters: Communiqué, 7 March 1812, p.13.

Vide J de Villiers, 'Die Cape Regiment, 1806-1817' (Archives Year Book for South African History, 1989 , I).
} 
soon became acquainted with all sectors of the local population and circumstances. He had many friends, but few enemies in his personal life. In his dealings with Landdrost van der Riet and Landdrost Stockenström he promoted equal treatment for all people before the law. ${ }^{65}$ Superiors, such as Governor Cradock, regarded Graham as most reliable and loyal, performing duties to the best of his ability and according to the convictions of his time. ${ }^{66}$

Was Graham the inventor of segregation on the Cape eastern frontier? Certainly not, but he applied it diligently as a practical and viable solution to the clash of different interests in a closing frontier situation. The Fish River boundary was an artificial, but official, man-made ruling since 1778. The cattle farming communities of both trekboers and Xhosa herders regarded the disputed Zuurveld as an ideal grazing land for their increasing stock. Graham did what he was required to execute as functionary of the Colonial government. After the expulsion of the perceived Xhosa intruders he made arrangements for the continued "safety and tranquility" on the frontier, in accordance with the recommendations of his predecessors and contemporaries, e.g. Major Richard Collins and Governor Cradock. ${ }^{67}$

In the light of recent demands for the gradual changing of names of places and institutions associated with racial segregation, ${ }^{68}$ the names of John Graham, Theophilus Shepstone, John Cradock and Benjamin D'Urban may be included. Graham, as much as other prominent leaders in our history, contributed substantially to the kaleidoscope of South African development. He must be judged within the time and context of his services. ${ }^{69}$ His record remained unblemished - sacrificing his best years in this country, promoting negotiations and reconciliation, but also firm in conviction and execution. ${ }^{70}$ Graham's intention on the eastern frontier was never to slaughter the Xhosa intruders, but to use the strongest military measures to compel them to accept the fait accompli of the integrity of the Fish River as official dividing line between the Colony and Xhosa territory.

Graham's subsequent role in the Napoleonic wars in Europe and his return to South Africa as Commandant of Simon's Town represent another chapter in his life story. His marriage to Johanna, daughter of Rudolph Cloete of Westervoort, Rondebosch, immediately after the frontier war, also confirms his affection to the Colony and its people. But in the last instance Graham never lost sight of his roots - Fintry in Scotland. ${ }^{71}$

Graham's handling of the case of the soldier Viool is a typical example. Vide C.A., C.O. 10 Sundry Civil and Military Officers : Graham - Cockell, 20 November 1808, no. 112 and Grey - Alexander, 24 December 1808, no. 116.

Vide Cradock's praise in the Proclamation of 14 May 1812 in the Cape Town Gazette and African Advertiser, p.1.

G.M. Theal (ed.), Records of the Cape Colony, VII (Report of Collins, 6 August 1809), pp.98-139. Jörn Rüsen, Studies in Metahistory (HSRC, Pretoria, 1993), pp. 180-183.

On one of the interior pillars of the Anglican Cathedral in Grahamstown is simply inscribed: "In memory of Colonel John Graham, Commandant of Simon's Town, Cape of Good Hope, who died 17 March 1821, aged 42 years". 


\section{The Dynamics of Early $19^{\text {th }}$ Century Nupe Wars}

Femi J. Kolapo ${ }^{\bullet}$

\section{The Nupe in Nigeria}

The Nupe of Nigeria inhabit the "low basin formed by the valleys of the Niger and Kaduna rivers, between $9^{\circ} \mathrm{E} 30^{\prime} \& 8^{\circ} \mathrm{E} 30^{\prime}$ north." They occupy an estimated total land area of about 7,000 square miles. ${ }^{1}$ With reference to a modern map of Nigeria, Nadel delineates Nupe's southern boundary to be a line

drawn from Leaba, on the Niger, eastward to Kataeregi marks the northern boundary of Nupe land, another line drawn eastward from Shari (or Tsaragi) to Abugi and on to the Niger south of Baro .... The Niger, flowing almost straight north-south between Leaba and Jebba, divides Nupe country from Yoruba in the west; the slowly rising country, east of Lapai and Gidi, sloping upward towards the hills of Gbari country, forms the eastern boundary of Nupe. ${ }^{2}$

The Nupe are composed of several groups of people of distinct dialects, two of which derived from outside of Nupeland. They speak different but mutually intelligible dialects of Nupe and live within contiguous geo-political boundaries. These subgroups include the Kusapa, the Chekpan, the Batachi, the Bini, the Kyedye, the Benu and the Gbedegi. The last two groups were said to have derived from Borno and Yorubaland respectively. ${ }^{3}$ To their immediate south and southeast are the Owe, Bunu, Yagba, Kakanda and a few clusters of the Bassa. The latter two groups are settled on the west-bank of the Niger river as far down as the point just above its confluence with the Benue in Igala territory.

Following the nineteenth century outbreak of the the Nupe war and its subsumption into the Sokoto jihad after which the Nupes were incorporated into the Sokoto caliphate, Nupeland was divided among the five emirates. These included Rabah/Bida, Lapai and Agaie, all to the north of the Niger, and Shonga and Lafiagi, to the south. The non-Nupe polities of Kakanda, Owe, Yagba, Bunu and Bassa, all became entangled in the Nupe war and ended up in different levels of political dependency vis-à-vis the Nupe

The Owe, Bunu and Yagba live further away from the flood plains. They are an inland agricultural people living in habiting the upland area on the southern border of the Nupe and west and southwest of the Kakanda and Bassa. Throughout the 19th century, the entire study area was convulsed in wars. other Nigerian societies were undergoing similar experiences around the same time. The Hausa states to the north were in the throes of the jihad wars of Uthman Dan

\footnotetext{
York/UNESCO Nigerian Hinterland Project and History Department, York University, Canada.

Forde, D., "The Nupe", Peoples of the Niger-Benue Confluence, London, 1955, p. 17.

Nadel, S. F., A Black Byzantium, London, 1942, p. 1; see also R. K. Udo, Geographical Regions of Nigeria, Berkerly, 1970, pp. 116-117.

For a fuller discussion, see Nadel, Black Byzantium, pp. 26-33; Mason, M., "Nupe Kingdom in the 19th century: A political History”, Ph.D dissertation, University of Birmingham, 1970, pp. 8-14, 26-31.
} 